\title{
Limitations of State Police in Nigeria
}

\author{
Eme Okechukwu Innocent \\ Ogbochie, Andrew N. \\ Department of Public Administration and Local Government Studies \\ University of Nigeria, Nsukka, \\ Email-okechukwunncnt@yahoo.com, okechukwunncnt@gmail.com
}

\section{Doi:10.5901/mjss.2014.v5n15p130}

\section{Abstract}

Blood has been literally, flowing in the streets of Abuja, Kano, Bauchi, Kaduna, Suleja and Maiduguri. Lives have been lost and property worth millions, destroyed. Apparently, there is no end in sight for this ugly development. No Nigerian is insulated from bomb explosion. Churches, mosques and corporate offices are not spared. In Lagos former Chief of Defence Staff Gen. Alani Akinrinade, urged the government to find a solution, warning that Nigeria was about being assailed by urban guerilla. Across the country, the fear of Boko Haram sect has become the beginning of wisdom. The violence unleashed by Boko Haram has been perfectly complemented by armed robbery and ritual killings across the six geo political zones. Ethnic clashes and kidnapping are also rife. In Jos, capital of Plateau State, mass burial of victims of ethnic conflict led to more blood letting on the spot. Now members of the National Youth Service Corps (NYSC) are rejecting postings to troubled spots with justification. On daily basis, there are cries of dependency and government appears to be helpless. Can the federal government restore security? What is responsible for all the sporadic bombings? Why has the North central and North East remained a troubled spot? These are puzzles that seem to have no answers. Just recently, governors were at a crossroads. Although, it is the north that is primarily under siege, southern governors could not turn their eyes away from the plight of their kinsmen who reside in these troubled spots. The Nigeria Governors Forum (NGE) proposed some measures. Taking a global look at the socio economic and political realities that may underlie insecurity, it suggested a sort of 'Marshal Plan' to tackle the trend. Some governors, lawmakers and opinion leaders also reiterated their clamour for state police. They highlighted the numerous assistance given to state police commands by governors, including donation of vehicles, uniforms, housing, guns, and even, bullets. He said it is illogical that the state governors, who are chief security officers, have no control over the police. Many reasons have been adduced for the state of insecurity ravaging the country. Some of them paled into conjunctures. But there is no evidence that government has got any lead as well. There is a monotony of assurances of normalcy from the Police Inspector General of Police (IGP), Mohammad Abubakar and Security Chiefs. To their consternation, the suicide bombers seem to have dwarfed security agents. This paper seeks to explore the limitations of state police as a panacea for insecurity challenges facing centralizing policing in Nigeria.

Keywords: Police and Policing, Security Threats/Challenges and Insecurity, Security Agencies, Federalism and Boko Haram

\section{Introduction}

The Senate recently renewed its call for state police to combat the rising cases of insecurity in the country. The latest push is against the backdrop of the recent killings in Abuja, Zamfara, Benue, Plateau, Kaduna, Taraba, Nassarawa and Katsina states by Boko Haram and cattle rustlers. The Senate also mandated its Committees on Security and Intelligence, Interior, Defence and Army and Police Affairs to undertake fact finding missions into the killings and report back to it.

These resolutions were sequel to the adoption of a motion sponsored by Senator Barnabas Gemade and five other senators titled "Recent Attacks and Killings in Plateau, Benue, Kaduna and other parts of the Central Nigerian Area". Deputy senate president Ike Ekweremadu who presided over plenary said with the current system of Federal Police, it will be very difficult to combat insecurity in the country hence the need to decentralise the police force. He further explained that it is unacceptable to have a federal system and still have a centralised police force, and stressed the need to have the force at every level of government in the country. According to him, "We must be able to provide sufficient police personnel that should be at least one policeman per 100 metres away. And this can only be achieved if we decentralise our Police, ensuring that we have State Police and possibly Local Police that are well coordinated and regulated. We had problem in the past in this area because they were not well regulated and they were not coordinated. 
Also worried by the level of insecurity in many parts of the country caused by the Boko Haram sect, and the fear that the nation is gradually collapsing, the 36 states governors under the aegis of the Nigerian Governors' Forum NGF, have called for the establishment of state police.

The Forum reiterated its commitment to convene a Governors Forum Conference on security in Nigeria. State governments are currently overstretched in funding security and called for a special intervention fund from the Federal Government, especially to the state that are most affected. Finally, the forum identified the increasing need for state police as a strategy for combating the rising insecurity in the country.

Also dissatisfied with the state of the nation, Deputy Senate President, Ike Ekweremadu recently noted, I and other Senators are worried about the state of insecurity in our country we are worried about the movement of people from one area to another especially on the strength of threat from Boko Haram. We are also worried about killings of people in places of worships. These things are like a bonfire, if not quenched, it can consume all of us (Kajo, 2013:5).

The Inspector-General of Police, Mohammed Abubakar, while dismissing the theses of state police agitators has again reiterated his objection to the establishment of state police in Nigeria, arguing that the country is not yet ripe for it. He cited several examples and asked the following questions:

Check countries of the world which are operating the state police, how many years of their independence? Take Britain, take United States, and take any European country that you can call as instance, we are talking of 2,000 years in the United States. How old are we? Do they have the challenges we have? Do they have the issue of where are you come from? Do they have the religious crisis that we have? Do they have the level of tribal differences in the states? Do they have such challenges? So, these are issues that should be put into consideration. "Do they have the same political issues that we have, the same political problems; that you want to contest as president but because you're not from the North, you cannot contest? Tell me one state in Nigeria today, where you have 'A' party in power and local government election is conducted and 'B' party wins all the seats. Why is it so? It's not state police. Now what happens, when you have a Commissioner of Police appointed by the state governor? (Ekundayo,2014:17).

Proponents of state police recommends that, the existing arrangement of deploying the bulk of the police to their indigenous states should be made constitutional. Second, both state and federal laws should be enforced. Third, structures of checks and balances which insulate the police from partisan politics and control by political officer holders should be put in place. But above all, the current skewed federal arrangement should be restructured with power, resources and responsibilities duly devolved to the state and local levels. This will leave the Federal Government more nimble, efficient and effective in carrying out those duties assigned it by the constitution. Irrespective of their argument State police could not scale through committee level at the National Conference recently. Its advocates failed to convince others in the committee on power devolution to transfer it to the concurrent list that would enable states to share power and responsibilities on it with the federal government. Delegates were divided as they argued along geo-political lines with Chief Ayo Adebanjo, Chief Gbade Adedeji, Senator Tony Adefuye, Chief Okey Ikedife and Chief Adeniyi Akintola in favour of a decentralized police. Alhaji Dambatta Magaji and Col Usman Farouk led the northern delegates' agitation against a decentralized police structure.

For the protagonists of state police, state governments have been funding the police as a result of the inability of the Federal Government to adequately cater for the institution. Chief Adebanjo, who noted that a decentralized police force was a key factor in a federal system of government, pointed out that note should be taken on the need to reduce the burden of governance in the Federal Government. According to him, if the country wanted federalism, it should not run away from the things that make a federation. For instance, the problem of Book Haram could have been better handled if the country had a police structure that could keep track on the local people and identify deviants before they get out of hand. Besides, he noted that the unitary structure of the police was largely responsible for the growing insecurity in Nigeria as men and officers of the Police were largely strangers in their places of assignment. Antagonists of the state police, led by former Governor of the defunct North Western State, Col. Usman Farouk, said criminals could commit crimes in one state and take refuge in another. This paper seeks to explore the challenges militating against the establishment of state police in Nigeria. To achieve this objective, the first section of the paper discusses conceptual issues. The next part explores the challenges of centralizing policing in Nigeria. The third section examines the contending theses of state police. The next highlights the militating factors against state police. The final section offers recommendation and concludes the paper.

\section{Clarification of Concept: Police}

It is a truism that the Police as one of the institutional structures of the state plays very important and powerful role in any given society. 'Police' refer to a particular kind of social institution with specific social functions. The police represent the 
civil power of government as opposed to the military power.

Ade (1990:94) affirms this contention and relates it to Nigeria's experience as a state going through the arduous and, oftentimes, tortuous process of nation building. Most developing countries, including Nigeria according to him, employ and engage the police as an instrument for enhancing socio-economic and political development.

According to Olewe and Anga (1994:2) the term "Police" is used primarily to denote, a body of people organized to maintain civil order and public safety, to enforce the law, and to investigate breaches of the law. In other words, Police is concerned with law enforcement. All societies, according to the authors, need some means of maintaining order. Albeit, Police function is to some extent universal in nature, they primarily serve to enforce Law and order in the society. The Nigeria Police, therefore, is the organized body of people established by law to perform police duties as provided for in the Nigerian Constitution. The 1999 constitution of the Federal Republic of Nigeria, section 214(1 \& 2) provides among others that:

There shall be a police force for Nigeria which shall be known as Nigeria Police Force and subject to the provision of this section, no other Police Force shall be established for the federation or any part thereof. The members of the Nigeria Police Force shall have such powers and duties as may be conferred upon them by law(FGN,1999).

The dynamics and complexities of modern society have made it imperative that for law, order, stability and good government to be maintained, there should be an appropriate and well equipped organ or agent of the state armed adequately with modern equipment/weapons, and expertise to enforce orderliness in the society. Such an organ/agent is expected to curb violations of peace, crime wave, apprehend criminals and protect lives and property as well as individual liberties. In Nigeria, the Police Force is charged with the aforementioned responsibilities. This is in accordance with the Police Act (1990), Part II Section 3, Cap. 359, which provided the impetus to the establishment of the Nigeria Police Force thus: "There shall be established for Nigeria, a Police Force to be known as the Nigeria Police Force".

Black (1979) defined police as the branch of government which is charged with the preservation of public order and tranquility, the promotion of public health, safety and morals and the prevention, detection and punishment of crimes. Lord Denning (1949:24) buttressed this definition by stating that an ideal police officer must be a young man (person) of excellent character and from good home (that is good background). The implication is that police authorities have a big task in the selection or recruitment of the right caliber of men and women into the force. To achieve these functions and tasks, Small (1984) observed that the police force have dual role to play in a given society:

(1) They are expected to protect the constitution of the society of which they are employed and perform other relevant duties in this regard. (2) While on duty, they should endeavour to avoid pressure from special interest groups, since that will reduce public confidence, without which their job could become not only difficult but also make conviction almost impossible. He further opines that police work is difficult and very sensitive, that this may be connected with why most people usually monitor the activities of policemen more than other government agents. Kennedy (1994) concludes by positing that policing a multicultural world is a key challenge to the police, that this challenge is compounded by contradictions inherent in maintaining public order on the one hand, and sustaining the freedom and wish of other members of the society.

\section{Challenges of Centralized Policing}

Palm (1979) asserts that the police was established to guarantee a crime free society. Viergiver (1995) adds that the development of the police has been largely influenced by the demands of society for relief from problems that cannot be solved in another way or totally solved. He maintained that if one commits crime, and everyone behaved reasonably, the need for a sophisticated police force would not arise at all. But since the above condition is difficult to attain, there will always be need for the police. Supporting these theses, Bunyard (1978) opines that the basic objectives of the police have not radically changed since their inception. He maintained that what has changed is in the way in which the force has responded to these objectives. Gillan (1988) observes that the duty of the policeman in the contemporary world is no longer restricted to acting as watchman and detectives, but has also expanded to include crime prevention by teaching people how to safeguard their own property, and the rule of law in order to divert them from breaking the law. However, Bunyard (1978) maintained that the resources at the disposal of the police and their implications for result oriented policing cannot be reconciled. This he claimed was as a result of the absence of an acceptance gauge or construct with which to measure crime prevention. Bunyard (1978) thesis supports Tamuno (1970) who maintained that the circumstances and situations in which the police perform their duties make it a rather hard process to evaluate the entire process of law and order maintenance. He opines that a number of persons may be resentful of the police but the society is generally handicapped to actually assess the extent to which the police perform its duties effectively. That the public expects much from the police which is ill-equips to actualize its set goals. He believes that a change of attitude of people 
towards the police would also imply a spontaneous acquisition of wonderful records and scores for the police. That for police to be effective and result oriented, good public relations must be established.

Okere (1994) on the other hand believes that most of the problems faced by police in carrying out their duties arise primarily from the fact that members of the police force are part and parcel of the society they police. This makes effective maintenance of law and order to be very problematic since the factors, which affect the host society do not spare the police force. Ozo-Eson (1994) adds that the aftermath of poverty, mal-distribution, and inequality in access to the good things of life creates a crime prone society. He believes that the unhealthy competition brought about by social aims and aspirations can become so pronounced that those who cannot cope are forced to fall out and develop disrespect for society and its values, which in turn can lead to a kind of alienation, desperation and crime.

Hampton (1960) summarizes the above theses by positing that the influence of globalization, coupled with the new culture of economic and political alliance among others have continually put to critical test the role of the institutional systems for law and order. He mentioned that the growing crises of law and order, the rising spate of crimes in the society, and crisis of unity among different cultural and religious groups noticed in various parts of the globe are pointers to the objective shortfall in the performance of the police force vis-à-vis the order maintenance responsibility. Hampton (1960) was able to establish a relationship between police, crime and order. According to him, the failure of police reflects on the state of the crime statistics and public order as well as generates fear and insecurity, thereby creating a crimeprone society.

In line with Hampton (1960), Alemika (1994) and Nweze (1997) have argued that the society creates the crime which the individual commits and that the Nigerian society, like every other society where inequality exists is prone to criminal activities. Alemika (1994) views this condition as a contradiction that a society which produces the objective conditions for crime should turn around to expect the police to prevent or reduce the level of crime. Similarly, Mbosowo (1994) maintains that policing a crime-infested society is an enormous task for the Nigerian police and that the social system in Nigeria is fraught with influences which may destabilize and cause disorder. He also maintained that little should be expected from the police under the prevailing limiting situation. This limiting and frustrating situation are evident in the level of force equipment, the involvement of its personnel in criminal activities.

Anderson (1979) argued that crime is inevitable and ineradicable in most societies. To him, crime prevention and order maintenance would be Herculean task for an ill-equipped police, partly because the price for a crime free society will be too high to pay in terms of resources and the administrative requirement. Again, the role of crime detection involves a given probability that it will deter people from committing crime and provide society with the opportunity to deal with the offenders as it deems fit, thereby helping to exonerate innocent persons, recover stolen property and satisfy a desire for revenge. The effectiveness of the police on crime prevention and detection are measured by level of insecurity and public disorder. Undetected crimes in the society impinge negatively on the entire society. The current security challenges in Nigeria have affected police responses to them.

Until 1966, the Nigeria Police Force co-existed with numerous local police forces, especially in the Northern and Western Regions. But during the First Republic (1960 - 66), there were widespread complaints against local police forces in the country. Besides the poor quality of personnel due to low standards of recruitment and training there were allegations that the governments in Northern and Western Regions used the local police forces to oppress political opponents and, especially, to rig elections. It was alleged that Northern and Western Regional governments converted members of the local police forces to political thugs during elections, while political thugs were massively recruited into the local forces and were used to harass and oppress members of the opposition party and to prevent free and fair political competition in the electoral process. As a result of the widespread allegations against the local police forces, the military government dissolved them and by 1970, they have nearly all ceased to exist. Majority of their members were absorbed into the Nigeria Police Force. The 1979 and 1999 Constitutions provided that there shall be no other police force in the nation except the Nigeria Police Force. Section 214(1) of 1999 Constitution provided that:

"There shall be a Police Force for Nigeria, which shall be known as the Nigeria Police Force, and subject to the provisions of this section, no other police force shall be established for the Federation or any part thereof"(FGN,1999)

Today, the increasing insecurity in the country has called into question the centralisation of policing in the country and the need perhaps, for non-centralisation to guarantee that states of the federation establish, maintain and control their police. Antecedent to this was the idea of community policing, based on the notion of cooperation between police officers and private citizens in communities to grapple with crimes and sundry social vices. Central to the idea is the neighbourhood principle that presupposes that everyone in the vicinity knows each other, thereby making it easy to monitor deviants in the community. These ideas have not yielded fruits. Worse still, the federal police are dysfunctional 
and not working. Indeed, it lacks adequate funding and suffers from limited manpower, besides being unwieldy. The need for a structural re-arrangement of the police marks the point of departure for all who are engaged with state police.

Beyond theory, regional police in the immediate post-independence period was used to suppress opposition in all the regions in the country. Prevailing intolerance, vindictiveness and absence of maturity of politicians suggest that it could still be used to suppress the opposition. This is the fear among many who, though desirous of the federal principle, would want some pragmatic ways to bring it into effect. Already in practice, but not enshrined in the constitution, is the deployment of a large number of police to their indigenous states and local governments. There is also a notable trend of massive funding of the police by state governments, some of who maintain unofficial security apparatuses. While these extant realities make the case for state police saleable, the inherent authoritarian trappings of the process based on present-day intemperance of political office holders cannot be dismissed simply.

The point that state police might be used to suppress non-indigenes living in some states could also have prompted the northern governors to balk on the issue and instead called for the amendment of section 215(2), which states that, "The Nigeria Police Force shall be under the command of the Inspector-General of Police, and any contingents of the Nigeria Police Force stationed in a State shall, subject to the authority of the Inspector-General of Police, be under the command of the Commissioner of Police of that State." The governors want an arrangement that will allow the chief executives of states to have operational control over the state commissioners of police. This is equally open to abuse by the state governors.

Nevertheless, what is not in doubt is that state police, in the long run, is inevitable. Therefore a transitional scheme that will lead to its creation is desirable. There are many problems associated with full scale centralized policing in the last three or four decades in Nigeria. There has been complaints of uneven distribution of policemen and material, with some states getting more than their fair share while others are left unmanned open to unchecked criminal activities; second, many states are also frustrated after committing huge state resources into federal police force yet having no real or legal control over their use and utility, third countless cases of men without knowledge of the local environment deployed to man or take charge of places, violating several local sensitivities leading to ineffective policing; fourth, cases of stunted careers of generations of officers not favoured by the political control of the police forces which led to lack or loss of morale and reduces professional out put.

To be sure, section 214(1) of the 1999 Constitution provides "There shall be a police force for Nigeria, which shall be known as the Nigerian police force and subject to the provisions of this section no other police force shall be established for the federation or any part thereof". Those are the words in the constitution. What the constitution has done is to limit the potential of effectively policing the Nigerian state by rigidly prescribing one single federal police force. Truth however is, as Nigeria continues to consolidate and evolve on its federal structure certain anomalous governance institutions must begin to give way for the federating units to take proper care of their local and state challenges. One of such is the police force and by extension the correctional centres, that is, the prison services. As a federal state prison service is obvious and a contradiction of the federal arrangement if otherwise and that is why this heady disagreement within the governors ranks only shows how frightful we often are to take first steps in solving obvious national problems. A new framework for effective policing is needed now.

There is the legal absurdity of a federal police enforcing state laws, prosecuting state laws in state courts, and incarcerating state offenders in federal prisons. That kind of arrangement does not allow effecting governance in a federal arrangement or even in a modern democratic state. No state government can budget properly for security and crime control and criminal management. The state governments cannot invest in more men to man the streets because they are federally provided the prisons are congested because states cannot bring state offenders into their budgeting lines. This is a fundamental problem in addition to the chain of command, which is directed elsewhere to the higher federal authority.

Now, only a few days ago, the Lagos State government signed into law a radical traffic regulation with stiff monetary penalties for offenders. This then is the issue: how can a federal police buy into the states traffic or policing agenda when the state may see huge revenue potential in the law and the matters thereto are peculiarly a state's local challenge? It is natural for some conflict and passivity to follow the enforcement of the law as both the legislative initiative and policing possibilities are of divergent sources. This is not to say that the said Lagos traffic law, as it stands, has or may enjoy popular acclaim knowing for example that infrastructure deficiencies bad roads, limited access ways, insecurity on the highways, lack of street lights, etc in part are often responsible for limited or outright non compliance with several road regulations. 


\section{State Police: The Contending Theses}

In the face of the deploring security situation confronting the nation at this time, some proponent of a state police believe that it is only a decentralisation of the force as practiced in most developed countries can rescue the nation from the precipice. Doing so, they maintain, will give room for the central command to focus on raising a crop of highly professional crop of central squad that may be deployed from time to time when the need arises. At present, the police strength is put at about 371,800 as against a population of 150 million Nigerians. Judged by the United Nations Standard, the number of available policemen is grossly inadequate as it does not meet the 400 to 1 ratio requirement. With a state police structure, the federating units would be able to determine their security needs and raise enough manpower to meet them (Eme, et. al, 2009:15).

Beside, each state has its own peculiar security challenges which can only be better managed by the officers who are familiar with the terrain, culture and way of life of a particular people in a given locality.

While for, instance, the trend of violence and criminally ongoing in the northern region bother essentially on religious fundamentalism, the South-East and South-South regions have always grappled with kidnapping, armed robbery, youth militancy and vandalism as their own peculiar security situation. Within the Southwest Region, especially Metropolitan Lagos, area boys syndrome and hooliganism have remained a unique future of the environment. It is, therefore, believed that only a decentralized police structure where people who hail from an area and are familiar with the terrain and the criminals in the neighborhood are entrusted with responsibility of policing that can carry out effective contain crime and criminality. In developed nations, the police are trained according to the peculiarities of the localities in which they operate.

Nevertheless, those on the other side of the fence are often too quick to puncture this argument. In the opinion of some stakeholders, creating state police at this stage of the present democratic experiment may be an invitation to chaos. Apart from the impunity of office and the possibility of abuse of power, state police could lead to the disintegration of the country, especially now with the fragile unity in the country.

In the pre-independence era, the Native Authorities were in direct control of their domains. It was the primary responsibility of the NA police to maintain law and order ion their respective localities. Through the NA police departments, the naïve authorities were able to enforce local ordinances, byelaws, rules and regulations of the localities or municipalities over which they presided. It was the intervention of the military in the nation's body politics that foisted a centralized police force on the entire country under the present quasi-unitary system of government.

Regardless of the pros and cons of the debates, creation of a State Police structure would also be a major leap in the nation's match towards the much cherished true federalism that has eluded the nation for a long time.

It is sine-qua non to genuine principles of true federalism. In the immediate post independent era when regional government was in direct control of its affairs, each region has its own police structure independent of the power at the centre. However, history has it that some regional political leaders abused local policing as the local police force was used as instrument of political intimidations and harassments against their opponents. Even now, the tendency is still very high for some over ambitious political leaders to turn state police to an instrument of apolitical vendetta. The immediate past experience in Anambra State where a sitting governor, Dr. Chris Ngige, was abducted in the broad day light through the connivance of the police is a good case in point. But the answer is neither here nor there. So, unless there is a proper reform and adequate checks and balances, state police can equally become a willing tool in the hands of the politicians, especially the overbearing ones.

A former Minister of Police Affairs and Governor of the old Oyo State, Gen David Jemibewon, has however suggested creation of Zonal police command as a way of forestalling abuse of power by the state governor. In an interview with Sunday sun, he said, "my view is that there should be state police"().

However, because there are 36 states now and if every state is to have state police, it means that there will be 37 police forces in Nigeria. That may be unwieldy. The $37^{\text {th }}$ will be federal police. Therefore, what Jemibewon advocated now is zonal police command. This is more so now that we have six geo-political zones in the country. And in doing so, we must ensure that the police officers in each zone are people who are domiciled there. For instance, if you have western police command, it must be made up of people who are residents in the western zone of the country. If anything happens, for example, the Northwest and the situation is so bad that you have to bring some policemen from other places, they will just decide which zone should contribute to that zone to deal with the situation. Under the arrangement, we may, however, have a single inspector General of Police and Deputy Inspector General in each geo-political zone.

There has been a lot of debates on the propriety or otherwise of allowing states to own their police forces or outfits in Nigeria. That America as the biggest democracy on earth has succeeded in the efficiency of state and even county (equivalent of local government) police is not news. What is however surprising is that Nigeria, the biggest democracy on 
the African continent which hopes to build the American model of governance and security is sometimes bedevilled by antagonists of the establishment of State Police forces. It is even more surprising when those who fire this salvo against the establishment of state police are those who have seen it all and benefited from it while in "God's own country" or elsewhere abroad.

That some states need State Police is not new and since the components parts of Nigeria cannot all develop at the same speed, those wishing to have this component of security apparatus should be allowed to have their way with requisite constitutional provisions guiding their operations. There is this argument that since there is already a federal police in place then there is no need to have state police in Nigeria. In the United States, the federal police (FBI) operate along with the state and county police. All have clearly demarcated boundaries of operation. Thus while state police operate within the geographical boundaries of the state, the federal police (FBI) are borderless and are often invited in complex cases by the state police. Thus, the argument that the recurring clashes at the Benue-Nasarawa border between Tiv farmers and Fulani herdsmen would have escalated into interstate disputes if state police were in place does not hold at all as each force will not be operating as an army of the states fighting to reclaim territorial boundaries. Thus in a metropolitan state like Lagos with interspersed dwellings from Ogun (example Akute area and others),the Police would be educated on the boundaries for patrol and can only make citizen arrests if the need arises whenever they cross to the other side.

Moreover, tax collectors in both states have been operating seamlessly for years without disputes over claims of territorial area. There will therefore be no anarchy as been speculated in some quarters about the advent of state police. Some have argued that Nigeria is not matured for state police. This argument is again hollow, for some states in Nigeria are more advanced than others and would have special need of it. States that don't need state police should be allowed to stay out of it and to develop at their own pace. The component parts of Nigeria cannot all develop at the same rate and time. The idea of a unitary decision to establish state police throughout the country does not hold, for states that need it should be allowed to establish such and mature with it. The case of Commissioner Mbu in Rivers State shows that the federal police may not be after all neutral in some circumstances. This does not mean that governors with state police will be working against the federal police. For it has been shown that most governors in the country have been working together with and supporting the federal police with working tools and logistics.

Funding of the state police has often being an issue especially with dwindling oil revenue to the federal government. But it is a known fact that no matter the paucity of funds, security votes to governors still runs into billions of naira and is largely unaccounted for. Some call it governors' free money. Governor Okorocha once popularised this when he said he was going to use the security vote to develop his own state of Imo instead of pocketing it as is done in some other states .While this is patriotic of him, it also sheds light on the fact that the state police will not be starved of funds when and where it will be in place. So security vote remains a yearly take off fund for state police where it will be operational. This means security vote has to be judiciously utilized. It is commendable that some governors have often used this to procure operational vans for the federal police operating in their domain. Funds for state police could also accrue from development partners who need such an institutional framework to provide support, state government budgetary allocations, benefactions and occasional support from the federal government as the need arises and justifiably so.

Give an inch and they will take a foot. So, some have asserted that when the request for state police is granted, the states would start demanding for State Prisons Service or even control of the Nigeria Prisons Service albeit the funding implications. This may not hold due to funding implications, but if it does, it would only imply an expanding need for such services in an ever growing population like Nigeria's. But if states can provide such services or in support at no expense to the federal government, then why bother. At least there is a state that built an elite prison for the federal government and it was not rejected. But again, Nigeria has a lot to learn especially from countries that have a federal system with state structures such as United States.

\section{Limitations of State Police}

The recent call for the establishment of state police has generated a lot of arguments from various quarters of the society. State governors across the country, in particular, are of the opinion that this would help check various dimensions of insecurity that has made governance a tough job for them.

Some of the reservations expressed against the establishment of state police include:Negative impact on Democracy: one of the major arguments against state police is that it will impact negatively on our nascent democracy. Thus, if states and local government authority are allowed to own their police forces, it would be used to perpetuate themselves in office at the detriment of the opposition (Tamuno,1970;184). This was experienced when the country 
practiced Regional and Local Government Police system shortly after independence. As Ohonbamu noted, "in the Western Region there were mass recruitment into the local forces of party thugs and stalwarts-people against whom the police were supposed to be giving protection to the law abiding citizens"(Ohonbamu,1972;75). He also noted that Northern Nigeria,

Political opponents were arrested by native authority police for holding private meetings to discuss political issues, handcuffed or chained and marched through the streets as an ocular demonstration of what fate awaited those who sought to exercise their fundamental rights (Ohonbamu,1972;76). Oppression and intimidation: it is also feared that the establishment of state would further increase the use of the police as an instrument of oppression as the ruling class and their friends would use it to intimidation and harass the general public. Rotimi gives us one of such consequences of the use of Regional police forces in the then Western Region:

A wedge was driven between the Native Authority and the public because the policemen also used their status to oppress their fellow-citizens through bribery, blackmail and District Officers, applauded the policemen for their 'good work'. They only occasionally frowned at misdemeanours such as: misappropriation of taxes and brutal treatment of culprits (Rotimi,1993;201).

National Disintegration: there is no doubt that the current unitary system of policing like other such programmes (e.g. the NYSC) serve to integrate the country. Cross country posting of police men and women make them to understand that Nigeria is broader than their various villages. It also enables the locals to interact with serving policemen from other regions. This therefore, fosters national integration and unity. The establishment of state and local policing will erode this attempt and national unity.

The Inspector-General of Police, Mohammed Abubakar, has taken a firm stand against the establishment of state police in Nigeria, saying the country is not yet ripe for it.

Abubakar, who marked two years in office early January, said in an interview published in the latest edition of the Chief Detective magazine posited that:

We are not yet ripe for state police. I'm not saying there shouldn't be state police; we are not yet ripe for it. I'll cite several examples. Check countries which are operating the state police. How many years of independence? Take Britain, take the United States, and take any European country that you can call. We are talking of 2,000 years in the they have the issue of where you come from? Do they have the challenges of 'I was born in Lagos, but l'm not a Lagosian?' Do they have the religious crises that we have? I'm a Muslim, you're a Christian? Do they have the level of tribal differences in the states- that I'm ljaw, you're Itsekiri, you're Igbo, or you're Eka-Igbo? Do they have such challenges? So, these are issues that should be put into consideration. Do they have the same political issues that we have- the same political problems, that you want to contest as president, but because you're not from the North, you cannot contest, or because you're not from the South or West or South-south or South-east you cannot contest, or it's not your turn? And I continue to ask questions. Tell me one state in Nigeria today where you have party A in power and local government election is conducted and party B wins all the seats. Why is it so? It's not state police. Now what happens when you have a commissioner of police appointed by the state governor? We just concluded the Anambra election, in Imo, we arrested 230 persons from Osun State with voters' cards, with ID cards of INEC. The commissioner of police arrested them, went to a hotel based on intelligence information, searched for them and got them, rigorously. Tell me what would have happened if the commissioner was appointed by the governor of Imo State. Would he have arrested them? Would he have prosecuted them? These are issues that we should consider very seriously (Ekundayo,2014:17).

Speaking on the way forward, Abubakar said:

What we need to do is to continue to build on our community policing projects. When it is time for state police, it will come to happen. And that is when, I was born in Lagos, whether I'm from Sokoto or Zaria, or from Maiduguri; I was born in Lagos, therefore I have the right to contest with anybody in Lagos. The constitution says 10 years. If you have stayed 10 years, you can contest. Today, most people who live in other states are not treated as citizens of that state. Is that the kind of country we want? So, which means you have been denied your fundamental right. But, nobody is talking about it. I'm sure time will come for state police. And what do you do if you have ethnic crisis in the state? If in my state, I'm a Hausa man, and I have Fulani, Ibo, and Yoruba people, and I'm the governor of the state. I appointed the commissioner of police in the state, who is a Hausa man like me, and Ibo people are fighting with Hausa. What will happen? The Commissioner of Police is Hausa, because it's a Hausa state. The DC is Hausa, the AC is Hausa, the DPOs are Hausa, all the policemen are Hausa; so what will they do with the Ibo, whether they are right or wrong? (Ekundayo, 2014:).

Abubakar added that several factors should be taken into consideration, concerning the issue of the Federal Police 
Force in terms of decentralization of powers, pointing out that most of the problems have been addressed by the Dan Malami and M.D. Yusuf reform in which the government accepted a certain number of suggestions and the present administration has completed all the police aspects of the reform.

\section{Recommendations}

Despite the myriad of calls for the creation of state police to address the lingering insecurity in parts of the country, the presidential committee on the re-organisation of the Nigerian Police Force has warned against the establishment of state police in Nigeria, warning that it can lead to the separation of the country. While submitting its report to President Goodluck Jonathan on Tuesday, called for reforms in the way the Nigerian Police Force is funded, this should involve the three tiers of government. Chaired by former Deputy Inspector-General of Police, Parry Osayande, the committee in its report stated that granting the Nigerian Police Force financial autonomy and reforming the National Police Council will annul the clamour for the creation of state police. "A stronger and more efficient National Police Council with effective participation of state governors; financial autonomy and better professionalism for the police will cancel demands for state police" (Binniyat,2012:44).

The Federal Government recently said that rather than ask for the creation of state police system, Nigerians should help the present police force to discharge its duty of protecting lives and property. Government also said that since crime-fighting had become scientific, new recruitment procedures into the Force be science based, adding that new recruits would be people that have science-related subjects. Former Minister of Police Affairs, Navy Captain Caleb Olubolade (rtd.), spoke to newsmen recently, after he briefed the leadership of Peoples' Democratic Party, PDP, of activities of his ministry. He said that the 1000 closed-circuit television, CCTV, already installed in Lagos and Abuja were ready for commissioning by President Goodluck Jonathan.

According to him, Vice President Namadi Sambo had already inspected the cameras and confirmed that they were working, adding

President Jonathan will soon commission the CCTV for public use. On state police, the minister said: My opinion is that we must make the present arrangement to work before we talk of new methods. The existing police must be trained and properly equipped so that we can be proud of the police we have. Our policemen are good and they have demonstrated this during peace keeping activities in other countries (Kajo,2013:5).

In amending sections 214, 215 and 216 of the Constitution relating to the Police Force Odiadi, (2012:8) recommends the following:

(a) Without prejudice to the foregoing provisions $(214,215$ and 216), a State of the Federation shall be free to establish and maintain a police service for the maintenance and securing of public safety within the State and enforcement of all relevant laws of the state.

(b) For the purpose of subsection the above such a State shall establish a police Training School regulated and compliant to standards in force in police in terms of discipline, schedule of duty, weaponry, ranks and promotions amongst other issues.

(c) The Head of the State Police shall be designated by the title Chief of Police who shall be appointed by the Governor on the advice of the state police service commission.

(d) Notwithstanding, the provisions in this section, a state of the federation shall be free to retain at all times the existence and services of the Nigerian Police for the purpose of maintenance and security public safety.

(e) Where the act of the Nigerian Police Force conflicts with that of State Police Service Force conflicts with that of state police service, that of the Nigerian Police force shall prevail.

(f) It shall be lawful for any person who feels that his right has been infringed upon by the state police service to apply to a federal high court to have his matter transferred to the offices of the Nigerian police force immediately within jurisdiction.

Finally, it must be stated that mindful of abuses which state authorities can deploy state police officers to several control systems were recommended by both committees. The federal police must exist across the country to check all abuses and violations of rights as its first original mandate. And so a state governor who imagines himself empowered to intimidate or oppress political opponents will face legal and constitutional restrains and controls. Only criminals would really be afraid when states begin to have their police forces.

\section{Conclusion}

The debate on whether the states should be permitted to recruit, train, fund and control own Police Force independent of 
federal government as obtains in the United Kingdom, Europe and United States of America is indeed very healthy for Nigeria's democracy. However, the focus of the debate is despicable. For the discerning, it is clear that there has been a steady dangerous twist with ethno-religious, communal colorations and internationalization of the crisis. But whichever side of the divide one finds himself, the ineptitude of the Nigeria Police is visible. Evidently too, the rising rate of mititarization of crimes across the length and breadth of the country, stoutly support this point. Indeed, one does not need to hire a prophet before coming to the understanding that the nation is currently doddering on an untamed monster following the activities of ethno- religious extremists. The situation is even more precarious when one considers the evident failure on the part of federal security agencies to respond to such security challenges as the sustained pipeline vandalization in the Niger Delta region, Oil theft, kidnapping, high octane murders and assassinations, killings, among others . This lacuna may have further aggravated the call for state police as a remedial measure.

There are no misgivings that the security challenges in the country are getting worse every passing day. Instead of improving, it is further deteriorating to its lowest ebb. The state of insecurity has indeed affected socio-economic activities, especially in the northern part of the country where killings and destruction of lives and property is well pronounced. In fact, in the history of Nigeria, there has never been a time the country witnessed serious security breach such as now. There is need however to proffer adequate mechanism in addressing this menace and not the call for a state police.

\section{References}

Ade, K. (1990), Nigerian Quest for Nation Building, Lagos: Touch Tone Press.

Alao, B. (1984) Today's Police Force: Perspective on its Operations, Uyo: Ufot Publishers.

Alemika, E. E. O. (1991). Policing Contemporary Nigeria. Problems and Prospects, Jos: Unijos Press.

Alemika, E. E. O. (1993). "Criminology, Criminal Justice and the Philosophy of Policing." in T. N. Tamuno, et al (eds), Policing Nigeria, Ibadan; University Press.

Alemika, E. E. O. (1993) "Colonialism, State and Policing in Nigeria." Crime, Law and Social Change 20: 189 -219.

Anderson, J. (1979). Policing Freedom, Plymouth: Macdonald and Evans Ltd.

Anstride C. (1961), Local Police Acts in Pre-independence Nigeria Lagos: Equity Publishers

Binniyat L. U (2012), "Nigeria not ripe for State Police, IGP Insists", Vanguard, Friday,July 6, P.44

Black, D. (1980). The Manners and Custom of the Police. New York. Academic Press.

Critcheley. T. A. (1972), History of police in England and Wales, 2nd edition. Montclair. N. J.

Dambazau, A. B. Criminology and Criminal Justice in Nigeria. Ibadan: Spectrum Books.

Dempsey, J. S. (1994). An Introduction to Law Enforcement. Minneapolis/St. Paul. MN: West.

Ehindero, S. E. (1998). The Nigeria Police and Human Rights. Jos: Ehindero Press.

Ekundayo, K. (2014), "Why Nigeria is not ripe for state police -IGP", Daily Trust, Monday, 27 January, P. 17.

Federal Republic of Nigeria (1999). The Constitution of the Federal Republic of Nigeria. (Abuja: Federal Ministry of Information). Section $214(1 \& 2)$.

Jones, R.V.(1965), The Nigeria Police Instructions Notes, Vol. 1, Lagos: Government Printers

Kajo, T.(2013), "Nigeria not ripe for State Police, Says Tsvar", Daily Sun, Thursday, June 28, P 5.

Macaulay, J. (1964), Policing the West for Her Majesty London: Panther Books Ltd.

Membere, C.F.L (1977). Police Studies Manual (Nigeria) Vol. 1, Lagos: UNICOM Books Ltd.

Nwaubeze, B. O. (1983), Federalism in Nigeria under the Presidential Constitution, London: Sweet and Maxwell.

Odekunle Femi (1979). "The Nigeria Police Force: A preliminary Assessment Functional Performance." International Journal of Sociology of Law.

Oderemi (2012), "Agitation for State Police: Real Police or Private Armies? Daily Sun, July 1, P, 8

Odiadi, T. (2012a) "State Police and Effective Policing in Nigeria (I)", Vanguard, Thursday, August 8, P. 52.

Odiadi, T. (2012b), "Controversy trails Governors Demand for State Police (2)", Vanguard, Friday, August 9, P. 52.

Ogunbuyi , W. (2011), "A Call for the Decentralizations of Nigeria Police", The Punch, May 12, P. 17.

Ohonbamu, O. (1972). "The Dilemma of Police Organization under a Federal System: The Nigerian Example." The Nigerian Law Journal (6), Pp. $73-87$.

Ojo, A et al, (2012), "Controversy Trails Governors' Demand for State Police", National Mirror June 28, Pp 1, 3-4.

Olewe B.N. and Anga J.S (1994), (eds.), Command Administration: The Police Perspective, Enugu: New Generation Book.

Oyawale, J.B. (2005), Policing Our Society, Ibadan: Pillar Pub.

Rotimi, T. (1993), "Local Police in Western Nigeria: End of an Era," in T. N. Tamuno, et al (eds), Policing Nigeria, Ibadan; University Press.

Samuel W. (1992). The Police in America: An Introduction, 2nd ed. New York: McGraw -Hill.

Tamuno, T. U. (1970), The Police in Modern Nigeria, Ibadan: University Press

The Laws of the Federation of Nigeria, Federal Ministry of Justice, Vol. xx. Police Act, Cap. 359, 1990. 
The Police Act, (1990), Cap 359, Part II, Section 3.

The Police Act, (1990), Cap 359, Part II, Section 5, p. 5

Tamuno, T. N. (1970). Police in Modern Nigeria. Ibadan: University of Ibadan Press.

Tamuno, T. N. (1989). The Role of the Police in the Maintenance of Internal Security. Kuru.

Tamuno, T.N., I. L. Bashir; E. E. O. Alemika and A. O. Akano, eds. Policing Nigeria: Past Present and Future. Lagos: Malthouse Press.

Tyokumbur, E. (2014), "Still on State Police", Daily Independent, Friday, March 21, P. 49. 